\title{
The Importance of Temporary Layoffs: An Empirical Analysis
}

EVERY GOOD theoretical or econometric study must be based on a reasonably accurate empirical foundation. If the basic magnitudes of the subject are misperceived, the theoretical model or econometric specification will lead the research astray.

In recent years, research on the central macroeconomic questions of unemployment and wage inflation has been advanced by the empirical studies of Hall, Holt, Parnes, Perry, Wachter, and others. Meanwhile, the U.S. Bureau of Labor Statistics has benefited the profession by expanding the data base with detailed monthly summaries of household and establishment data and through the provision of complete data from the Current Population Survey.

All of this microeconomic evidence has greatly enriched understanding of the nature of unemployment. The traditional view, based on the experience of the depression, pictured the unemployed as an inactive pool of job losers who had to wait for a general business upturn before they could find new jobs. Modern research has shown that this picture is distorted. The majority of the unemployed do not become unemployed by losing their previous jobs; they quit voluntarily or are new entrants or reentrants into

Note: I am grateful to the National Science Foundation for financial support, to Alan Auerbach and Pamela Hannigan for research assistance, to Thomas F. Bradshaw of the Bureau of Labor Statistics for providing unpublished tabulations, and to Richard B. Freeman and members of the Harvard seminar in labor economics for useful discussions. 
the labor force. Moreover, the typical duration of unemployment is very short; more than half of unemployment spells end in four weeks or less.

However, one very important aspect of unemployment has been largely ignored: temporary layoffs. In my 1972 study for the Joint Economic Committee, I noted that during 1971 manufacturing firms rehired about 85 percent of the same workers that they had laid off. ${ }^{1}$ This remarkable statistic whetted my appetite for more information about temporary layoffs-that is, unemployment without job change. Since then I have examined a number of sources of unpublished data on the phenomenon and I am now convinced that it is of great importance and requires a major reevaluation of current theories of unemployment.

Despite their obvious importance, no data on temporary layoffs are currently published. My purpose in this paper is to present a range of new empirical information on temporary layoffs that can provide a foundation for future analytic and econometric research. The evidence is based on the analysis of unpublished data from the U.S. Manpower Administration's National Longitudinal Survey of work experience of older men, from the Current Population Survey of March 1974, and from special monthly tabulations of job seeking since 1970 made by the Bureau of Labor Statistics. The paper goes on to analyze the manufacturing turnover data that first aroused my interest in temporary layoffs. Finally, I will comment briefly on some of the implications of temporary layoffs for the theory of unemployment, wage rigidity, the Phillips curve, and unemployment insurance. ${ }^{2}$

\section{Definitions of Unemployment}

Because the official terminology of unemployment statistics is unfamiliar, some definitions are in order. Estimates of unemployment are based on a national household survey, the Current Population Survey. If an individual reports that he is not working but that he has looked for work in specified

1. Martin S. Feldstein, Lowering the Permanent Rate of Unemployment, A Study Prepared for the Use of the Joint Economic Committee, 93 Cong. 1 sess. (1973), p. 12.

2. For a first step toward an explicit theory of temporary layoffs, see my "Temporary Layoffs in the Theory of Unemployment," Journal of Political Economy (forthcoming, June 1976). That paper deals with some but not all of the issues raised in the concluding section below. 
ways within the past four weeks, he is classified as unemployed. ${ }^{3}$ The means of looking for work include checking newspaper ads and talking to friends as well as seeing employers or employment agencies.

However, looking for work is not the only criterion of unemployment. An individual who has a new job that he is planning to start within thirty days is classified as unemployed even if he has not looked for work within the past four weeks. Far more important, those who are on layoff from a job are counted as unemployed. Any individual who reports that he did not work at all during the week before the survey is asked, "Did you have a job (or business) from which you were temporarily absent or on layoff last week?" Those who answer "yes" are then asked, "Why were you absent from work last week?" Answers involving illness, weather conditions, and vacation are not considered unemployment. But an individual is regarded as unemployed if he reports that he is on layoff from his regular job and expects to be recalled. Thus, an individual can be unemployed even though he responds that he has a job. Moreover, these individuals are not even asked about their job-seeking activity in the past four weeks.

Individuals with a job but on layoff are classified into two groups. Someone with a definite date of expected recall within thirty days is classified as on "temporary layoff" while all others are classified as on "indefinite layoff." Since all layoffs are expected to be temporary in some sense, I will refer to the first group as "fixed-duration layoffs" and the second group as "indefinite-duration layoffs."

The term "layoff" is also used by the Bureau of Labor Statistics somewhat differently in describing manufacturing turnover on the basis of data reported by establishments rather than households. In that context, layoffs are defined as "suspensions without pay lasting or expected to last more than 7 consecutive calendar days, initiated by the employer without prejudice to the worker." 4 This definition of layoffs includes permanent separations as well as temporary layoffs, but excludes discharges "for cause" and compulsory retirements as well as separations initiated by the workers.

Persons designated as unemployed in the Current Population Survey are

3. A single adult in the household describes the employment and unemployment experience of everyone in the household. It would therefore be more accurate to say, "If it is reported that an individual is not working but. ..." I will not bother to make this distinction in the remainder of the text.

4. Employment and Earnings, vol. 22 (November 1975), p. 135. 
classified according to four "reasons" for unemployment: job losers, job leavers, new entrants, and reentrants. The definitions are complex and not always intuitively obvious. Job losers include individuals on layoff-of both fixed and indefinite duration-even though they state that they have a job from which they consider themselves to be absent without pay. Individuals who already have a new job at which they will begin work within thirty days are also classified as job losers if they lost their previous job rather than quitting or being new entrants or reentrants. Finally, a job loser can be anyone who actually lost his previous job without expectation of recall and has, in principle, been looking for work since then. In practice, looking within the past four weeks is the only job-seeking test for someone who says that he started looking when he lost his previous job.

A job leaver is one who quit his previous job and has been looking for work since then. A new entrant is one who never worked before at a fulltime job lasting at least two weeks. Reentrants are essentially a residual category, including individuals who quit or lost their previous jobs but who have been out of the labor force before starting the current period of job seeking.

\section{Unemployment without Job Change: The National Longitudinal Survey of Older Men}

One of the four National Longitudinal Surveys that were conducted for the Department of Labor provides information on unemployment and job changes during the five years from 1966 to 1971 among men aged 45 to 59 in $1966 .{ }^{5}$ Because these data cover the same group of men over five years, they permit study of the frequency of unemployment without job change (that is, change of employer) and of job change without unemployment.

The importance of temporary layoffs during the first year of the survey is shown by the first column of table 1. During the year, 9.4 percent of men

5. The survey was directed by Herbert Parnes and conducted by the Bureau of the Census; for a description, see U.S. Department of Labor, Manpower Administration, The Pre-Retirement Years: A Longitudinal Study of the Labor Market Experience of Men, Manpower Research Monograph 15, vol. 2 (1970). The four surveys covered only selected subgroups of the population: men aged $45-59$, women aged $30-44$, and young persons aged 14-24 of both sexes. 
in this age group experienced some unemployment. ${ }^{6}$ Even among men with no job change during the year, 4.2 percent experienced unemployment. Indeed, this group accounted for 40.5 percent of all weeks of unemployment and 49.5 percent of all unemployed persons. One reason why so much of the unemployment occurs among those who do not change jobs is that nearly two-thirds ( 65.8 percent) of those who do change jobs do so without experiencing any unemployment. Finally, the mean number of weeks of unemployment is much shorter for those who experience temporary layoffs (8.2 weeks) than for those who are unemployed while changing jobs (11.8 weeks).

The data for the entire five-year period provide even stronger evidence of the importance of temporary layoffs. In this longer period 21.2 percent of those with no job change had at least one spell of unemployment and 61 percent of those experiencing unemployment did not change jobs. Again, 40 percent of the weeks of unemployment were experienced by those with no job change. Although 11 percent had changed jobs during one year, only 21 percent changed jobs during the five-year period, which suggests that job changing is concentrated in a small group with multiple job changes.

Even these figures understate the importance of temporary layoffs. Since some of those who change jobs also experience temporary layoffs, the percentage of all weeks of unemployment accounted for by temporary layoffs exceeds the 39.7 percent experienced by those with no job change.

Table 1 also compares the unemployment experience of the older men in different industries in 1966-67 and 1966-71. The estimates for manufacturing for the single year are similar to those for all industries except that a substantially higher percentage of weeks of unemployment is accounted for by those with no job change ( 54.8 percent) and a substantially higher fraction of unemployment spells involves temporary layoffs (62.6 percent of persons experiencing unemployment have no job change). Workers in wholesale and retail sales exhibited a quite different pattern in 1966-67, but the five-year evidence suggests that it was a highly atypical year. The construction industry sustained a much higher unemployment rate; nearly one-third of its employees in this age group were unemployed,

6. The survey data are weighted for the sampling fractions so that rates are representative of the relevant population. Unlike the practice in the Current Population Survey, the interview was always with the man himself in this survey. 


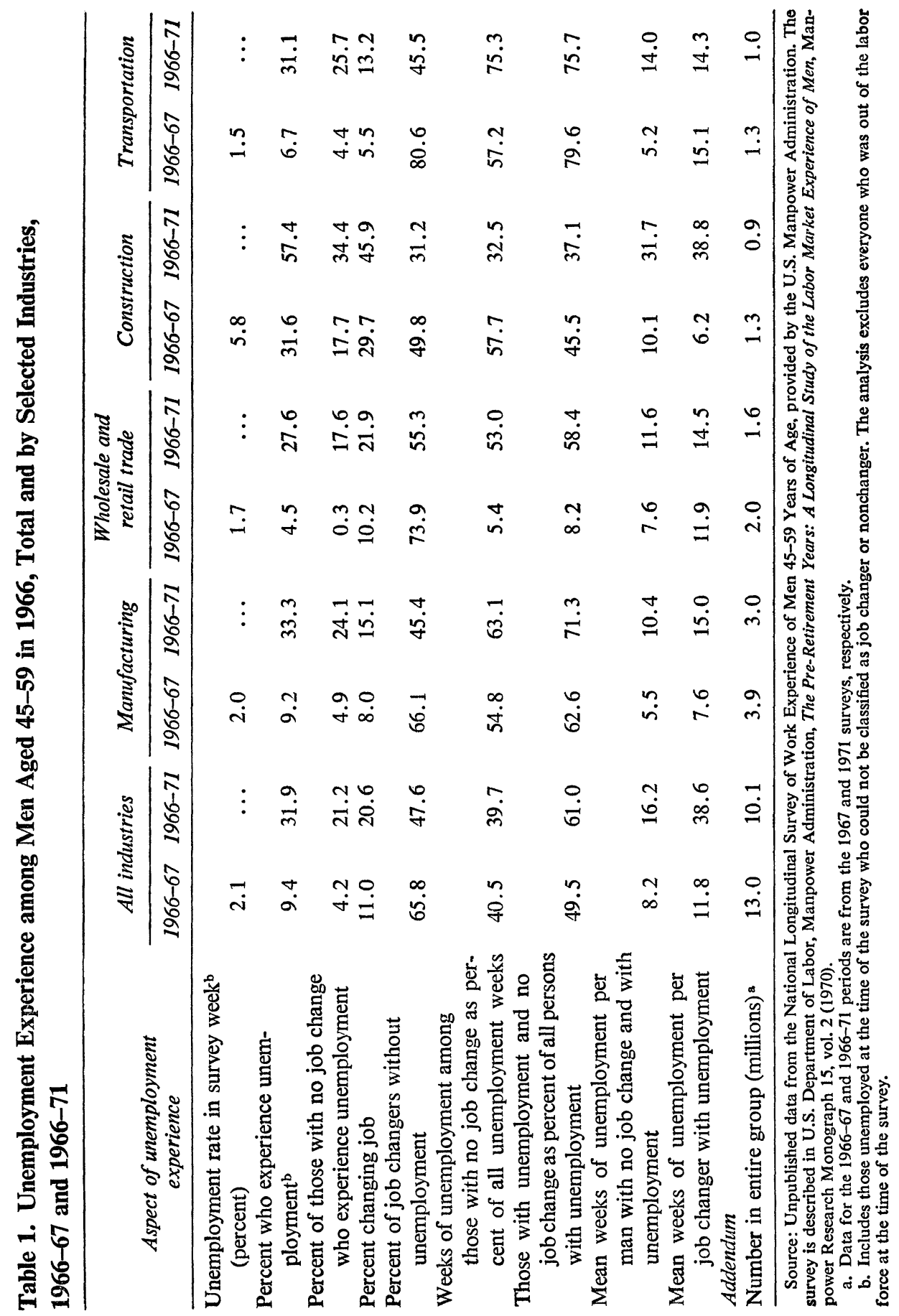


but almost half of them and nearly 60 percent of the weeks of unemployment are accounted for by those with no job change. Temporary layoffs are even more important in transportation, as revealed in the table. The fiveyear experience by industry, presented in the second column for each industry in table 1, again shows that temporary layoffs are relatively most important in manufacturing and transportation.

In short, the National Longitudinal Survey shows that most older men who experience unemployment do so as the result of temporary layoffs and most who make job changes do not experience a spell of unemployment.

\section{Layoffs without Job Loss: The Current Population Survey}

The Current Population Survey, the source of the official estimates of unemployment, is a monthly survey of approximately 45,000 households. Although the CPS does not make it possible to follow an individual over a period of time, as does the National Longitudinal Survey, it has the advantage of a very large sample that is representative of the entire labor force. The survey also provides detailed information on the numbers of job losers and of temporary layoffs.

This section analyzes the March 1974 survey. The overall unemployment rate of 5.3 percent (5.1 percent seasonally adjusted) was only slightly above the postwar average, and marked the beginning of the continuous rise in

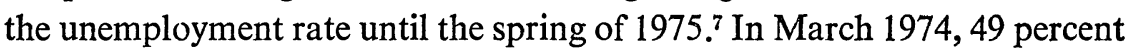
of the unemployed were job losers; the remainder were new entrants into the labor force ( 11 percent), reentrants ( 25 percent), and those who had quit their previous jobs (15 percent). Young people accounted for a very large fraction of new entrants and reentrants, and women reentrants for a substantial fraction of the unemployment not associated with job loss. Among men aged 25 to 64, 73 percent of the unemployed were job losers.

Table 2 shows the distribution of job losers among those on layoff, permanently separated, and scheduled to start a new job within thirty days. Layoffs account for 37.4 percent of all job losers and 40.4 percent of men aged 25 to 64 who had lost their previous jobs. Thus, a high proportion of

7. The March survey in each year collects information on family and individual incomes during the previous year. I had acquired these data for a different study that requires such information. As far as I can tell, March 1974 is not very different from other periods before the recent recession. 
Table 2. Percentage of Job Losers on Layoff, with No Jobs, or with Jobs Starting Soon, and Duration of Unemployment, March 1974

\begin{tabular}{|c|c|c|c|c|c|c|}
\hline \multirow[b]{3}{*}{$\begin{array}{l}\text { Group and } \\
\text { characteristic }\end{array}$} & \multicolumn{6}{|c|}{ Job status } \\
\hline & \multicolumn{3}{|c|}{ With job, on layoff } & \multirow[b]{2}{*}{$\begin{array}{l}\text { No } \\
\text { job }\end{array}$} & \multirow{2}{*}{$\begin{array}{c}\text { New job } \\
\text { starting } \\
\text { within } \\
30 \text { days }\end{array}$} & \multirow{2}{*}{$\begin{array}{c}\text { All } \\
\text { job } \\
\text { losers }\end{array}$} \\
\hline & Total & $\begin{array}{c}\text { Fixed } \\
\text { duration }\end{array}$ & $\begin{array}{l}\text { Indefinite } \\
\text { duration }\end{array}$ & & & \\
\hline \multicolumn{7}{|l|}{ All persons } \\
\hline Percent of all job losers & 37.4 & 10.1 & 27.3 & 61.4 & 1.2 & 100.0 \\
\hline Percent of all job losses ${ }^{\mathbf{a}}$ & 56.1 & 32.2 & 23.9 & 42.4 & 1.4 & 100.0 \\
\hline \multicolumn{7}{|l|}{ Percent of job losers } \\
\hline who search ${ }^{b}$ & 10.1 & 3.8 & 12.4 & 63.3 & 11.6 & 42.8 \\
\hline Mean duration (weeks) & 8.5 & 2.9 & 10.6 & 13.4 & 7.8 & 11.5 \\
\hline \multicolumn{7}{|l|}{ Men aged $25-64$} \\
\hline Percent of all job losers & 40.4 & 13.0 & 27.4 & 58.1 & 1.5 & 100.0 \\
\hline Percent of all job losses ${ }^{\mathrm{a}}$ & 60.0 & 36.0 & 24.0 & 38.6 & 1.5 & 100.0 \\
\hline \multicolumn{7}{|l|}{ Percent of job losers } \\
\hline who search b & 11.9 & 4.6 & 15.4 & 81.4 & 0.0 & 52.1 \\
\hline Mean duration (weeks) & 8.9 & 3.6 & 11.4 & 15.0 & 10.2 & 12.4 \\
\hline
\end{tabular}

Source: Tabulated from unpublished data from the March 1974 Current Population Survey provided by the U.S. Bureau of Labor Statistics. Figures are rounded.

a. A job loss is a new spell of unemployment that creates a job loser. These relative frequencies of unemployment are estimated on the assumption that the mean duration of completed spells is proportional to the mean duration of uncompleted spells in the survey week for each of the four mutually exclusive types of unemployment reported here.

b. Percent of job losers who looked for work during the week before the survey.

"job losers" have actually reported that they "have a job from which [they were] temporarily absent" during the week examined by the survey.

Only 10 percent of those on layoff said they were looking for work when asked what they had been doing during the previous week; among men aged 25 to 64, only 12 percent were looking. ${ }^{8}$ In contrast, among job losers with no job, 63 percent were looking for work; the proportion for men aged 25 to 64 was 81 percent. Unemployed workers on layoff clearly act as if they will be recalled. ${ }^{9}$

8. Recall that the report on the individual's activity may be made by some other household adult. Although those on layoff are not asked about their job seeking during the past four weeks, all of the unemployed are asked about their activities during the previous week.

9. Although looking for work is required as a condition of receiving unemployment insurance in many states, this requirement is often waived in practice for those on layoff who are expected to return to their original jobs. Individuals could, of course, satisfy such an unemployment-insurance requirement without regarding themselves as looking for work during the relevant week. 
Laid-off personnel can also be divided into those with a fixed duration of less than thirty days and those with a variable or indefinite duration. The first group accounts for 27 percent of all layoffs ( 32 percent among primeage men). Looking for work was very uncommon in both groups.

Even these very high proportions of the unemployed who are on layoff understate the frequency of new layoffs relative to new permanent separations. The unemployment rates understate this relative frequency because the mean duration of layoffs is substantially shorter than that of other job losses. Table 2 shows that the mean duration of unemployment until the time of the survey is 11.5 weeks for all job losers; but it is only 8.5 weeks for those on layoff while it is 13.4 weeks for those with no job. The relative frequency of the type of separation within the flow of new job losses can be estimated with the assumption that the mean completed durations of unemployment are proportional to the mean durations up to the date of the survey. ${ }^{10}$ This implies that 56 percent of all "job losses" are actually temporary layoffs rather than permanent separations: for men of 25 to 64, layoffs account for 60 percent of all "job losses."

Table 3 compares the characteristics of job losers and job losses in four major industry groups. In manufacturing, temporary layoffs are especially important, accounting for 50.6 percent of job losers among men aged 25 to 64 and 79.9 percent of job losses.

Table 4 shows the actual duration of unemployment spells (up to the survey date) by type of job loser. While 31 percent of those with no job have been out of work for four weeks or less, among those on layoff the fraction is much higher-44 percent. Similarly, while 12.4 percent of those with no job have been out for more than twenty-six weeks, only 3.7 percent of those on layoff have been out that long.

\section{Manufacturing Layoffs and Rehires}

I turn now to the statistics on manufacturing turnover that first aroused my interest in temporary layoffs. Manufacturing establishments are re-

10. The mean duration of completed spells is less than the mean duration of spells to the date of the survey; see Hyman B. Kaitz, "Analyzing the Length of Spells of Unemployment," Monthly Labor Review, vol. 93 (November 1970), pp. 11-20. The assumption of proportionality is unlikely to introduce more than a second-order error but deserves more detailed examination. The calculation of the relative number of job losses uses the separate information on fixed-duration and indefinite-duration layoffs. 
Table 3. Characteristics of Job Losers and Duration of Unemployment, by Selected Industries, Men Aged 25-64, March 1974

\begin{tabular}{|c|c|c|c|c|c|}
\hline \multirow[b]{2}{*}{ Characteristic } & \multicolumn{5}{|c|}{ Industry } \\
\hline & $\begin{array}{l}\text { Manu- } \\
\text { facturing }\end{array}$ & $\begin{array}{l}\text { Wholesale } \\
\text { and retail } \\
\text { trade, finance, } \\
\text { business } \\
\text { and repair } \\
\text { services }\end{array}$ & $\begin{array}{l}\text { Con- } \\
\text { struction }\end{array}$ & $\begin{array}{l}\text { Trans- } \\
\text { portation } \\
\text { and } \\
\text { public } \\
\text { utilities }\end{array}$ & $\begin{array}{c}\text { Total, } \\
\text { all } \\
\text { industries }\end{array}$ \\
\hline & \multicolumn{5}{|c|}{ Job losers (percent) } \\
\hline \multicolumn{6}{|l|}{ With job, on layoff } \\
\hline Fixed duration & 21.5 & 5.4 & 10.4 & 15.8 & 13.0 \\
\hline Indefinite duration & 29.1 & 13.4 & 36.0 & 34.0 & 27.4 \\
\hline No job & 47.5 & 79.4 & 52.6 & 47.7 & 58.1 \\
\hline \multirow[t]{2}{*}{$\begin{array}{l}\text { New job to start } \\
\text { within } 30 \text { days }\end{array}$} & 1.9 & 1.8 & 1.0 & 2.5 & 1.5 \\
\hline & \multicolumn{5}{|c|}{ Job losses (percent) } \\
\hline \multicolumn{6}{|l|}{ With job, on layoff } \\
\hline Fixed duration & 58.4 & 27.6 & 18.2 & 48.8 & 36.0 \\
\hline Indefinite duration & 21.5 & 9.3 & 32.0 & 21.4 & 24.0 \\
\hline No job & 18.4 & 62.1 & 44.8 & 27.7 & 38.6 \\
\hline \multirow[t]{2}{*}{$\begin{array}{l}\text { New job to start } \\
\text { within } 30 \text { days }\end{array}$} & 1.7 & 1.0 & 5.0 & 2.1 & 1.5 \\
\hline & \multicolumn{5}{|c|}{ Mean duration of unemployment (weeks) } \\
\hline With job, on layoff & & & & & \\
\hline Fixed duration & 2.5 & 2.3 & 5.7 & 3.2 & 3.6 \\
\hline Indefinite duration & 9.2 & 16.9 & 11.2 & 15.7 & 11.4 \\
\hline No job & 17.5 & 15.0 & 11.7 & 17.0 & 15.0 \\
\hline $\begin{array}{l}\text { New job to start } \\
\text { within } 30 \text { days }\end{array}$ & 7.6 & 20.7 & 2.0 & 12.0 & 10.2 \\
\hline
\end{tabular}

Source: Same as table 2. Figures are rounded.

a. Average durations and job-loss percentages based on small percentages of job losers are subject to substantial sampling variation.

quired to report each month the number of separations, divided into quits, layoffs, and "other separations," and the number of accessions, divided into new hires and "other accessions," where accessions are defined as "the total number of permanent and temporary additions to the employment roll, including both new and rehired employees." Layoffs in this context include some permanent separations as well as temporary ones. More formally, layoffs are "suspensions without pay lasting or expected to last more than 7 consecutive calendar days, initiated by the employer without prejudice to the worker." Other separations not counted as layoffs include "terminations of employment because of discharge, permanent disability, 
Table 4. Percentage Distribution of Duration of Unemployment among Job Losers, Men Aged 25-64, March 1974

\begin{tabular}{|c|c|c|c|c|c|c|}
\hline \multirow{3}{*}{$\begin{array}{c}\text { Weeks of } \\
\text { unemployment } \\
\text { up to date of } \\
\text { survey }\end{array}$} & \multicolumn{6}{|c|}{ Job status } \\
\hline & \multicolumn{3}{|c|}{ With job, on layoff } & \multirow[b]{2}{*}{$\begin{array}{l}\text { No } \\
\text { job }\end{array}$} & \multirow{2}{*}{$\begin{array}{c}\text { New job } \\
\text { starting } \\
\text { within } \\
30 \text { days }\end{array}$} & \multirow{2}{*}{$\begin{array}{l}\text { Total } \\
\text { job } \\
\text { losers }\end{array}$} \\
\hline & Total & $\begin{array}{c}\text { Fixed } \\
\text { duration }\end{array}$ & $\begin{array}{l}\text { Indefinite } \\
\text { duration }\end{array}$ & & & \\
\hline $0-4$ & 44.3 & 87.4 & 23.5 & 30.7 & 66.5 & 36.7 \\
\hline $5-10$ & 23.8 & 6.0 & 32.5 & 20.1 & 0.0 & 21.3 \\
\hline $11-14$ & 17.4 & 2.6 & 24.5 & 13.6 & 11.0 & 15.1 \\
\hline $15-26$ & 10.7 & 0.0 & 15.9 & 23.3 & 22.5 & 18.3 \\
\hline $27-39$ & 2.4 & 4.0 & 1.7 & 6.2 & 0.0 & 4.6 \\
\hline 40 and over & 1.3 & 0.0 & 2.0 & 6.2 & 0.0 & 4.1 \\
\hline Mean & 8.9 & 3.6 & 11.4 & 15.0 & 10.2 & 12.4 \\
\hline
\end{tabular}

Source: Same as table 2. Figures are rounded.

death, retirement, transfers to another establishment of the company, and entrance into the Armed Forces" for more than thirty days. ${ }^{11}$

Table 5 shows the very high turnover rate in manufacturing. Since 1960, manufacturing firms averaged 1.6 layoffs per 100 employees per month. During the same period, these firms were rehiring 1.3 persons per $100 \mathrm{em}-$ ployees per month. The rehire rate - that is, the ratio of rehires to layoffsaveraged 85 percent and did not drop below 70 percent in any year. ${ }^{12}$ In short, the vast majority of those laid off in manufacturing are ultimately rehired by their original employers, although in some cases they take jobs elsewhere in the interim. This is further confirmation of the estimates based on household surveys reported in the preceding two sections..$^{13}$

11. Employment and Earnings, vol. 22 (November 1975), p. 135.

12. Rehires are calculated as the difference between total accessions and new hires; they include a small number of persons arriving from intrafirm transfers who were not previously counted as layoffs. Although separate estimates of the numbers of rehires and transfers are not available, discussions with the Massachusetts Department of Employment Security confirmed that the number of transfers is small. Telephone interviews with the individuals who prepare the turnover report for each of the six largest manufacturing employers in the Boston metropolitan area disclosed that reported transfers were never greater than 5 percent of other accessions. Two firms did not regard transfers as separations or accessions and therefore did not count them as part of turnover.

13. When those who are laid off take other, temporary, jobs before being recalled, the CPS data classify them as employed. Thus, the existence of temporary jobs does not distort the statistics recording the importance of temporary layoffs among the unemployed. 
Table 5. Layoff and Rehire Rates in Manufacturing, 1960-75 ${ }^{2}$

Per 100 employees; average of seasonally adjusted monthly rates

\begin{tabular}{cccc}
\hline Year and quarter & Layoffs & Rehires & $\begin{array}{c}\text { Ratio of rehires } \\
\text { to layoffs }\end{array}$ \\
\hline 1960 & 2.4 & 1.6 & 0.7 \\
1961 & 2.2 & 1.9 & 0.9 \\
1962 & 2.0 & 1.6 & 0.8 \\
1963 & 1.8 & 1.5 & 0.8 \\
1964 & 1.7 & 1.4 & 0.8 \\
1965 & 1.4 & 1.2 & 0.9 \\
1966 & 1.2 & 1.2 & 1.0 \\
1967 & 1.4 & 1.1 & 0.8 \\
1968 & 1.2 & 1.1 & 0.9 \\
1969 & 1.2 & 1.0 & 0.8 \\
1970 & 1.8 & 1.2 & 0.7 \\
1971 & 1.6 & 1.3 & 0.8 \\
$1972: 1$ & 1.2 & 1.3 & 1.1 \\
2 & 1.2 & 1.2 & 1.0 \\
3 & 1.1 & 1.1 & 1.0 \\
4 & 0.9 & 1.0 & 1.1 \\
$1973: 1$ & 0.8 & 0.8 & 1.0 \\
2 & 0.8 & 0.9 & 1.1 \\
3 & 0.9 & 1.0 & 1.1 \\
4 & 1.0 & 0.9 & 0.9 \\
$1974: 1$ & 1.3 & 0.9 & 0.7 \\
2 & 1.1 & 1.1 & 1.0 \\
3 & 1.2 & 1.0 & 0.8 \\
4 & 2.4 & 1.1 & 0.5 \\
$1975: 1$ & 2.9 & 1.8 & 0.6 \\
2 & 2.4 & 1.9 & 0.8 \\
3 & 1.6 & 1.6 & 1.0 \\
\hline
\end{tabular}

Sources: Employment and Earnings, vol. 22 (December 1975), and vol. 19 (April 1973), tables D-1 and D-3 in each.

a. "Layoffs are suspensions without pay lasting or expected to last more than 7 consecutive calendar days, initiated by the employer without prejudice to the worker." Other separations not included in layoffs are "terminations of employment because of discharge, permanent disability, death, retirement, transfers to another establishment of the company, and entrance into the Armed Forces" for more than thirty days; see Employment and Earnings (November 1975), p. 135. Rehires are calculated as the difference between total accessions and new hires; they include a small number of intrafirm transfers.

\section{Cyclical Variations in Temporary Layoffs}

Although the information on temporary layoffs that is collected by the CPS is not currently published, some indirect evidence has been available since $1973 .{ }^{14}$ Each month Employment and Earnings reports the number of

14. See Thomas F. Bradshaw, "Jobseeking Methods Used by Unemployed Workers," Monthly Labor Review, vol. 96 (February 1973), pp. 35-40. 
job losers who were seeking work during the past four weeks. Anyone who is officially classified as unemployed who has not sought work during the past four weeks is either on layoff or planning to start a new job within thirty days. Table 2 gave evidence that the latter group accounts for about 3 percent of those on layoff. The number of job losers who did not seek employment during the past four weeks (the "nonseekers") can therefore be used as a reasonably accurate measure of the number on layoff..$^{15}$

Table 6 presents quarterly averages of the numbers of unemployed, of job losers, and of nonseekers since $1970 .{ }^{16}$ The final column displays the substantial cyclical variation in the ratio of nonseekers to job losers. Layoffs accounted for only 24 percent of all job losers in the third quarter of 1973 (when the unemployment rate was a relatively low 4.8 percent) but 47 percent of all job losers in the first quarter of 1975, when the unemployment rate reached a peak of 9.1 percent (not seasonally adjusted). The average ratio for the period was 33 percent, close to the 37 percent for March 1974.

The column next to the last shows the marginal share of temporary layoffs among all job losers. On average over the period, temporary layoffs contributed 58 percent of the quarter-to-quarter change in job losers. ${ }^{17}$ The important implication is that temporary layoffs constitute an even higher percentage of the cyclical variation in unemployment than they do in the static picture suggested in the section on the CPS.

\section{Some Implications}

I believe that the theory of unemployment and the analytic framework of econometric analyses must be revised to reflect the great importance of

15. The Current Population Survey does not ask anyone who is on layoff or about to start a new job about his job-seeking activities during the past four weeks. All of these persons are counted as nonseekers even if they have looked. All other unemployed must have done some job seeking to be counted as unemployed. This published information is separate from the question about search during the previous week that is asked of all the unemployed and reported in the section above on layoffs without job loss.

16. Data since 1973 are based on monthly figures published in Employment and Earnings; unpublished data were provided by the Bureau of Labor Statistics and are available only since January 1970 . By focusing on nonseekers among job losers I can exclude those nonseekers who are about to start a new job but are new entrants, reentrants, or persons who quit their previous job. The number of nonseeking job losers is the published figure that corresponds most closely to the number of persons on layoff.

17. This average excludes the three quarters in which the number of job losers changed too little (less than 5 percent) to permit a meaningful calculation. 
Table 6. Cyclical Variation in Job Seeking by Job Losers, Quarterly, 1970-75

Not seasonally adjusted; numbers of persons in thousands ${ }^{\mathrm{a}}$

\begin{tabular}{|c|c|c|c|c|c|}
\hline $\begin{array}{l}\text { Year } \\
\text { and } \\
\text { quarter }\end{array}$ & $\begin{array}{c}\text { Total } \\
\text { unemployed }\end{array}$ & $\begin{array}{l}\text { Job } \\
\text { losers }\end{array}$ & $\begin{array}{c}\text { Job losers } \\
\text { not seeking } \\
\text { employment }\end{array}$ & $\begin{array}{l}\text { Ratio of } \\
\text { incremental } \\
\text { nonseekers to } \\
\text { incremental } \\
\text { job losers }\end{array}$ & $\begin{array}{c}\text { Ratio of } \\
\text { nonseekers } \\
\text { to job } \\
\text { losers }\end{array}$ \\
\hline 1970:1 & 3,644 & 1,737 & 736 & $\ldots$ & 0.42 \\
\hline 2 & 3,867 & 1,582 & 554 & 1.17 & 0.35 \\
\hline 3 & 4,340 & 1,762 & 653 & 0.55 & 0.37 \\
\hline 4 & 4,501 & 2,142 & 831 & 0.47 & 0.39 \\
\hline 1971:1 & 5,343 & 2,877 & 1,080 & 0.34 & 0.38 \\
\hline 2 & 4,859 & 2,212 & 672 & 0.61 & 0.30 \\
\hline 3 & 5,077 & 2,124 & 654 & $0.20^{\circ}$ & 0.31 \\
\hline 4 & 4,692 & 2,112 & 693 & $-3.25^{\circ}$ & 0.33 \\
\hline 1972:1 & 5,358 & 2,697 & 906 & 0.36 & 0.34 \\
\hline 2 & 4,822 & 2,050 & 568 & 0.52 & 0.28 \\
\hline 3 & 4,897 & 1,941 & 526 & 0.39 & 0.27 \\
\hline 4 & 4,284 & 1,767 & 477 & 0.28 & 0.27 \\
\hline 1973:1 & 4,677 & 2,156 & 709 & 0.60 & 0.33 \\
\hline 2 & 4,274 & 1,571 & 436 & 0.47 & 0.28 \\
\hline 3 & 4,308 & 1,444 & 349 & 0.69 & 0.24 \\
\hline 4 & 3,959 & 1,520 & 417 & 0.89 & 0.27 \\
\hline 1974:1 & 4,967 & 2,473 & 943 & 0.55 & 0.38 \\
\hline 2 & 4,608 & 1,852 & 563 & 0.61 & 0.30 \\
\hline 3 & 5,115 & 1,892 & 556 & $-0.18^{\circ}$ & 0.29 \\
\hline 4 & 5,612 & 2,604 & 935 & 0.53 & 0.36 \\
\hline 1975:1 & 8,283 & 5,029 & 2,341 & 0.58 & 0.47 \\
\hline 2 & 8,004 & 4,491 & 1,781 & 1.04 & 0.40 \\
\hline 3 & 7,809 & 4,045 & 1,397 & 0.86 & 0.35 \\
\hline
\end{tabular}

Sources: Employment and Earnings, various issues, tables A-1, A-15, and unpublished tabulations from the U.S. Bureau of Labor Statistics. See text note 16 for additional information.

a. Quarterly average of monthly data for persons 16 years of age and over.

b. Nonseekers are those unemployed job losers who did not seek work within the past four weeks. An individual must be on layoff or planning to start a new job within thirty days in order to be counted as unemployed without job search.

c. Based on changes in job losers of less than $\mathbf{5}$ percent and therefore an unreliable statistic.

temporary layoffs. In this section I will sketch some of the other ways in which I believe the current view of unemployment should be altered.

\section{SEARCH THEORY}

During the past decade, the best of the modern work on unemployment has developed Stigler's analysis ${ }^{18}$ of search behavior with a model in which

18. George J. Stigler, "The Economics of Information," Journal of Political Economy, vol. 69 (June 1961), pp. 213-25. 
the unemployed worker samples job offers until he finds one that exceeds his optimal reservation wage. ${ }^{19}$ Like all good ideas, the application of search theory to unemployment is easily carried too far. In contrast to the earlier Keynesian view, later theories commonly equate unemployment with search and job change. The evidence in this paper shows that this equation does not hold for the substantial portion of unemployment that stems from layoffs that are temporary, end in recall, and involve no search.

Therefore, an explanation of why temporary layoffs are the norm, and what the implications are for the theory of wages and employment, is important. The question has two aspects. First, why does employment typically last so long even when demand varies enough to induce temporary layoffs? The answer involves a broad concept of firm-specific human capital that includes not only specific technological know-how but also such things as management's knowledge of the worker's ability and reliability; friendships within the workforce that make for greater productivity; and the employees' preference for stable employment, which implies a willingness to work for lower wages in order to reduce the prospect of involuntary job change. The effect of unemployment insurance on this decision also deserves attention. The independent role of unions and seniority systems must be separated from the unions' codification of an arrangement that would exist in any competitive labor market.

Second, given that some employees are in effect permanently associated with a firm, what determines the firm's response to a fall in demand? To what extent is it expressed in temporary layoffs, inventory accumulation, price reduction, and variation in hours? In the special case of a price-taking firm with no inventories, a powerful effect of unemployment insurance can be demonstrated. A more general analysis of a price-setting firm with inventories would be a useful extension.

19. This work includes Robert J. Gordon, "The Welfare Cost of Higher Unemployment," $B P E A, 1: 1973$, pp. 133-95; Robert E. Hall, "Turnover in the Labor Force," $B P E A, 3: 1972$, pp. 709-56; and Hall, "The Process of Inflation in the Labor Market," $B P E A, 2: 1974$, pp. 343-93; Charles C. Holt, "How Can the Phillips Curve Be Moved to Reduce Both Inflation and Unemployment?" in Edmund S. Phelps and others, Microeconomic Foundations of Employment and Inflation Theory (Norton, 1970); J. J. McCall, "Economics of Information and Job Search," Quarterly Journal of Economics, vol. 84 (February 1970), pp. 113-26; Dale T. Mortensen, "Job Search, the Duration of Unemployment, and the Phillips Curve," American Economic Review, vol. 60 (December 1970), pp. 847-62; George L. Perry, "Unemployment Flows in the U.S. Labor Market," BPEA, 2:1972, pp. 245-78; and Edmund S. Phelps, Inflation Policy and Unemployment Theory: The Cost-Benefit Approach to Monetary Planning (Norton, 1972). 


\section{VOLUNTARY VERSUS INVOLUNTARY UNEMPLOYMENT}

Search theory implies that the ending of a spell of unemployment reflects a voluntary act by the unemployed worker, who has decided to stop searching. In contrast, a layoff that begins the spell of unemployment is involuntary-not chosen by the employee. The current emphasis on quasi-permanent employment and temporary layoffs requires a reconsideration of this distinction between voluntary and involuntary unemployment.

For those on layoff, the return to work results not from a voluntary decision by the employee but from recall by the employer. However, the decision rule that leads to layoffs and that governs their duration is chosen by the employees, either explicitly in collective bargaining or by the operation of a competitive labor market. Although any particular spell of unemployment may be involuntary, the rules for layoffs are part of the package of wages, hours, and work-sharing rules that employees choose or for which they bargain.

\section{THE PHILLIPS CURVE}

The Friedman-Phelps explanation of the short-run Phillips curve also requires reexamination. According to this now familiar story, the short-run statistical Phillips curve exists because the unemployed are induced to stop searching when an unanticipated general increase in the wage level tricks them into thinking that they have found a particularly good job. The natural rate of unemployment-the rate at which the long-run Phillips curve is vertical-depends (according to this theory) on the optimal duration of search of the unemployed.

This theory must be overhauled to reflect the fact that so much of the cyclical variation in unemployment reflects the temporarily laid off, who do not search, and that so much job change occurs without unemployment. Given these conditions, a statistical Phillips curve could easily be observed even if no job searchers were being tricked in the way that Friedman and Phelps suggest. An increase in demand for firms' products would reduce the rate of layoffs and therefore lower the rate of unemployment. Firms would also seek to hire new workers away from other firms and to prevent other firms from attracting away their own employees, and wages would rise as part of this process. Thus, periods of increased demand for output 
would witness a lower rate of unemployment and a higher rate of wage inflation-a statistical Phillips curve. Of course, these wage increases would be in addition to any resulting from anticipated inflation. Layoffs and job changes without unemployment thus provide an explanation of the observed short-run Phillips curve that does not rest on the misperceptions of the unemployed.

This explanation of the observed relation between unemployment and wage inflation is quite different from the theory originally suggested by Phillips. He interpreted the unemployment rate as a measure of the supply of labor, with a greater supply putting downward pressure on wage rates. Subsequent studies by Lipsey and others used the difference between the unemployment rate and the vacancy rate to measure excess supply. ${ }^{20}$ In contrast, the vast majority of unemployed workers on layoff are not part of the supply of workers to other firms and should not be compared with the number of vacancies. Those on layoff have little effect on the supply conditions in the labor market but reflect the demand for labor by firms.

\section{WAGE INFLEXIBILITY}

The downward inflexibility of wages has long been a crucial puzzle in macroeconomics. For many Keynesians, it is simply a datum with important implications. Some have tried to explain it in terms of institutional constraints or government regulations. More recently, Baily and Gordon have suggested that wages are stable because workers are risk averse while firms are risk neutral. ${ }^{21}$ However, the risk-avoidance logic of the BailyGordon model requires that firms stabilize real wages while the evidence is that many wages adjust slowly to changing prices and are rarely (if ever) fully indexed.

Temporary layoffs and quasi-permanent employment provide two new and important reasons for downward wage rigidity. First, if workers are associated with a firm quasi-permanently, wage rates are explicitly or implicitly a long-term arrangement. Since the workers and the firm stay to-

20. Richard G. Lipsey, "The Relation between Unemployment and the Rate of Change of Money Wage Rates in the United Kingdom, 1862-1957: A Further Analysis," Economica, n.s., vol. 27 (February 1960), pp. 1-31.

21. Martin N. Baily, "Wages and Employment under Uncertain Demand," Review of Economic Studies, vol. 41 (January 1974), pp. 37-50; Robert J. Gordon, "The Microeconomic Foundations of Wage Rigidity" (Northwestern University, 1974; processed). 
gether, what matters is the average relation over the cycle between the wage rate and the marginal revenue product of labor. There is no reason to adjust wages continually..$^{22}$ The stability of the wage rate under these conditions of employment is reinforced by the difference between labor's and management's information about demand conditions and labor's justifiable suspicion of any management claim that wages must be cut because of weak demand. An explicit or implicit contract that requires layoffs (and the resulting loss of production) instead of wage cuts is a method of "keeping management honest" in this situation of unequal information.

Second, the fact that most of the cyclical variation in unemployment among job losers, and thus much of the cyclical variation in the unemployment of mature men, involves temporary layoffs is relevant to downward rigidity for a different reason. Because those who are on layoff so rarely take other permanent work, this source of variation in the number of unemployed represents only a tiny variation in available labor. Most of those who are on layoff do not force wage rates down by accepting new jobs with lower wages; and firms do not reduce their offers, because they do not observe a significantly greater availability of experienced workers. Because the mature men who are unemployed are primarily on layoff, much new hiring in this age and sex group must still be done by attracting those who are already employed.

\section{UNEMPLOYMENT INSURANCE}

The current analysis also sheds light on the role of unemployment insurance in the U.S. economy. Much of the discussion of the disincentive effect of unemployment insurance has focused on the duration of search. I have emphasized more generally that unemployment insurance affects not only this duration but also the frequency and duration of temporary layoffs and the relative importance of seasonal, cyclical, and temporary jobs.

This paper shows the potential significance of inducing more layoffs and extending their duration. The exact relation between unemployment insurance and temporary layoffs deserves careful study. A theoretical analysis indicates that the current poor method of experience rating and the exclusion of unemployment insurance benefits from taxable income imply a very

22. The overtime premium does cause some cyclical variation in the average wage rate and may enable management to increase hours in the short run. 
large subsidy to temporary layoffs. A careful econometric evaluation remains to be done.

The greater relative frequency of temporary layoffs among the insured unemployed than among the uninsured unemployed also affects the measurement of the impact of unemployment insurance on the duration of unemployment. ${ }^{23}$ Since temporary layoffs tend to be substantially shorter than other types of unemployment, ${ }^{24}$ if unemployment insurance had no real effect on the duration of unemployment, the average duration of insured unemployment would be less than the duration of uninsured unemployment. More generally, a comparison of the mean durations of the insured and uninsured unemployed tends to understate the extent to which unemployment insurance lengthens the average duration of each unemployment spell. ${ }^{25}$ Moreover, to the extent that unemployment insurance induces additional temporary layoffs, it may lower the mean duration of unemployment while increasing total unemployment.

\section{THE SOCIAL COST OF UNEMPLOYMENT}

Hall has suggested that the social cost of unemployment may be substantially less than the value of the lost output. ${ }^{26}$ However, his "inventory" approach to the optimal rate of unemployment assumes that the unemployed are a reserve available for other firms to hire. This premise is clearly false for the large number of workers who are on layoff. Most of this group does not engage in productive job search and is not available to other firms. The social cost of an unemployed worker on layoff is thus equal to the worker's lost output reduced only by his value of leisure. ${ }^{27}$

23. Almost all temporary layoffs will be insured while new entrants and many reentrants will be uninsured. Even among job losers, those on temporary layoff are most likely to have the required experience.

24. See the sections above on the National Longitudinal Survey and the Current Population Survey.

25. See Stephen T. Marston, "The Impact of Unemployment Insurance on Job Search," BPEA, 1:1975, pp. 13-48, and my discussion in the same issue, pp. 52-58.

26. Robert E. Hall, "Turnover in the Labor Force," BPEA, 3:1972, pp. 709-56, and "An Aspect of the Economic Role of Unemployment" (paper presented to the International Economic Association Conference on the Microeconomic Foundations of Macroeconomics, S'Agaro, Spain, April 1975; processed).

27. Gordon, in "Welfare Cost of Higher Unemployment," argued that unemployment has a high social cost, but his method understates that cost by assuming that the unemployed are job changers and use their unemployment for at least some job search. 


\section{CONCLUSION}

These cursory remarks on the implications of temporary layoffs can only suggest a direction for research and for modifications of the current theory. I hope that this evidence of the empirical importance of temporary layoffs will convince others that these theoretical and empirical developments deserve prompt attention.

\section{Discussion}

A NUMBER of participants commented on the implications of Feldstein's statistics for the relevance and validity of the search theory of unemployment. Some argued that temporary layoffs did not fit the search model, but instead resembled the kind of unemployment that Keynesians had stressed in the thirties: people losing their jobs, recognizing without exhaustive search that no satisfactory substitutes were available, and hence waiting for recall. Feldstein responded that, in contrast to the "old" view of unemployment, according to which laid-off workers have long periods of joblessness and basically must await a general business upturn before regaining their jobs, many of those on temporary layoff have very short durations and are recalled even though the economy has not recovered. James Tobin was particularly impressed by the evidence in table 1 on the large number of job switches made with no intervening spell of unemployment, a phenomenon he regarded as devastating to any claim that search theory could serve as a general explanation of unemployment. Robert J. Gordon recalled his finding $(B P E A, 1: 1973)$ that the unemployed spend their time mainly in waiting rather than searching.

Robert Hall, on the other hand, argued that neither job shifts without unemployment nor temporary layoffs without search were inconsistent with search theory. In his view, search theory explains why jobless people may wait and not take the very first job that becomes available. It does not preclude their taking a job without waiting, and thus avoiding any spell of unemployment, if that job is good enough. Nor does it preclude their judgment that it doesn't pay to search actively if they believe the probability of prompt recall is high and the probability of finding a better job in the 
interim is very low. Feldstein responded that, while in a formal sense all nonsearching could be viewed as a special case of search, that interpretation did not help to explain the unemployment of the nonsearchers.

A number of distinctions between workers on temporary layoff and the other unemployed were discussed. George Perry noted that, when those on temporary layoff are taken separately, it becomes clear that the rest of the unemployed are much worse off in terms of duration and of weekly probability of finding a job than is implied by the averages for all unemployed people. Charles Holt reminded the group of earlier studies that had found marked differences in the job-seeking behavior and the duration of unemployment between those who had been laid off and the rest of the unemployed. Michael Wachter conjectured that the people waiting for recall were probably heavily concentrated in high-wage industries; he suspected that those who lose jobs in low-wage industries generally find a job elsewhere rather than waiting for recall. This hypothesis could be tested if the data identified the previous occupational and industrial affiliations of the temporarily laid-off workers.

Tobin cautioned against any inference that those on temporary layoff had no influence on the excess supply of labor during a recession. Even if they did not actively search, they created "negative vacancies" since they would be rehired before their employers generated any unfilled vacancies. Similarly, Arthur Okun cautioned against any inference that people who ultimately returned to their previous jobs had remained unemployed during the entire period of layoff. On the contrary, considerable evidence suggested that a substantial fraction found interim jobs elsewhere. First, the employment of prime-age men in service industries is countercyclical, indicating that those low-paying sectors provide a temporary refuge for workers laid off from cyclical industries. Second, the rise in the unemployment rate of manufacturing workers during the recent recession was considerably smaller than the cumulative excess of layoffs over rehires shown in table 5. Many of those who had escaped from the category of unemployed factory workers must have found other jobs. Okun also observed that, if the incentive to employers to make temporary layoffs had greatly increased over time as a result of unemployment insurance or any other consideration, declines in output during recessions should now generate more unemployment, and correspondingly less shortening of hours and reduction of productivity. Yet he saw no evidence that the relationship between reduced output and incremental unemployment had shifted. 